\title{
Breast Cancer and Socioeconomic Status in Austria
}

\author{
Ursula Kunze Gabriela Böhm \\ Institute for Social Medicine, Center for Public Health, Medical University Vienna, Austria
}

Key Words

Breast cancer - Socioeconomic status · Austria

\section{Summary}

With $28 \%$ of all cancers, breast cancer is the most common cancer in the Austrian female population (also worldwide), and incidence has shown a development similar to that in most of the Western European countries. Several studies reveal a higher incidence of breast cancer in women of higher socioeconomic status (SES) compared to women of lower SES. Later age of first childbearing, low total parity, significantly greater use of hormone replacement therapy, and a greater use of mammography screening by women of higher SES are possible explanations for these trends. Socioeconomic inequalities have a strong influence on the subjective perception of health, but also on objective indicators of the health situation. The health behavior of the Austrian population is, of course, determined by social factors. People with a higher socioeconomic status not only live longer than people with a lower SES, they also have a healthier lifestyle and they better assess their own health status. These inequalities can also be observed in significant differences in life expectancy between university graduates and low-educated people (6.2 years for men and 2.6 years for women).

\section{Introduction}

Breast cancer is the largest women-related health problem - with about 1.3 million women worldwide receiving the diagnosis 'breast cancer' and 465,000 dying yearly - and, after lung

\author{
Schlüsselwörter \\ Brustkrebs · Sozioökonomischer Status · Österreich
}

\section{Zusammenfassung}

Mit 28\% Anteil an allen Malignomen ist das Mammakarzinom das häufigste Karzinom der Frau in Österreich (ebenso weltweit). Die Inzidenzentwicklung war ähnlich der in den meisten europäischen Ländern. Zahlreiche Studien zeigen eine höhere Inzidenz bei Frauen mit einem höheren sozioökonomischen Status im Vergleich zu Frauen mit einem niedrigen sozioökonomischen Status. Das höhere Alter bei der ersten Geburt, die insgesamt niedrigere Fertilität, ein signifikant höherer Gebrauch von Hormonersatztherapie und eine größere Inanspruchnahme der Mammographie bei Frauen mit einem hohen sozialen Status sind mögliche Erklärungen für diese Trends. Sozioökonomische Unterschiede haben einen starken Einfluss auf die subjektive Wahrnehmung von Gesundheit, stellen aber auch objektive Indikatoren der individuellen gesundheitlichen Situation dar. Das Gesundheitsverhalten der Österreicher ist selbstverständlich von sozialen Faktoren determiniert. Menschen mit einem höheren sozialen Status leben nicht nur länger als Menschen mit niedrigem sozialen Status, sie leben auch gesünder und schätzen ihre eigene Gesundheit besser ein. Diese Ungleichheiten schlagen sich auch in der Lebenserwartung mit signifikanten Unterschieden zwischen Akademikern und Menschen mit geringer Schulbildung nieder (6,2 Jahre bei den Männern und 2,6 Jahre bei den Frauen).

cancer, it is the second highest cause of cancer deaths among women [1].

Breast cancer is the most common form of cancer among females, although incidence and mortality rates vary significantly between countries. East Asian women still have the

\begin{tabular}{ll}
\hline KARGER & $\oplus$ 2009 S. Karger GmbH, Freiburg \\
Fax +49 761 4520714 & Accessible online at: \\
Information@Karger.de & www.karger.com/brc \\
www.karger.com &
\end{tabular}


lowest incidence rate $(21 / 100,000)$, compared to $101 / 100,000$ in the USA and 85/100,000 in Western Europe [2]. Breast cancer incidence has been increasing in virtually all regions since 1973 [3], but first signs of stabilization have been observed [4, 5]. Decreasing mortality rates could be monitored in Europe during the 1990s, with an annual percent change in the European Union of $-2.1 \%$ between 1995 und 2000 [6].

Many studies have addressed the effects of socioeconomic factors like education or income on the risk of the development of several diseases [7-11]. A relationship between socioeconomic status (SES) and incidence, mortality rate and survival due to cancer, cardiovascular disease, ischemic heart disease, metabolic disease, etc. is widely accepted. Data show consistently that a higher SES is associated with decreased incidence and mortality. Socioeconomic inequalities have a strong influence on the subjective perception of health, but also on objective indicators of the health situation. In particular, differences in, e.g., educational level, work status, income level or marital status have an impact on the socioeconomic situation and thereby on the health status of each person [11].

A study in eight Western European countries calculated a higher mortality rate among the most common specific causes of death in the low-educational group in comparison with the high-educational group, but breast cancer is an exception [8]. Several studies reveal a higher incidence of breast cancer in women of higher SES compared to women of lower SES [12-15].

This report concentrates on Austrian data of some selected socioeconomic variables where current data have been available. It is the purpose of the authors to describe the Austrian status quo regarding breast cancer risk factors and possible health inequalities.

\section{Risk Factors}

The etiology of breast cancer is still poorly understood, with some known risk factors which can, however, account for only a part of the cases (table 1). It is not possible to calculate exactly how much influence each of the individual risk factors such as genetics, lifestyle, environment, socioeconomic and cultural backgrounds, the reproductive behavior, diet and exercise behavior will have [16]. The following paragraphs give a short overview of the most important known or suspected risk factors:

- Being a woman: To be a woman means a $100 \%$ relative risk of developing breast cancer.

- Age: Age is the main risk factor, increasing with age. Breast cancer in young women is rare; from the 40th and 50 th year of life, the risk increases many times over. The risk of a woman of 25 years compared to a woman of 45 years of developing breast cancer is $1: 20$ [17].

- Family burden: Between 5 and $10 \%$ of all breast cancer cases show a hereditary background. Women carrying mu-
Table 1. Risk factors for developing breast cancer

\begin{tabular}{ll}
\hline Parameter & Relative risk \\
\hline Male/female & $1: 100$ \\
Age 25 years/45 years & $1: 20$ \\
Menopause with 42 years/52 years & $1: 2$ \\
Menarche with 14 years/11 years & $1: 1.3$ \\
Multipara/nullipara & $1: 1.3$ \\
First birth with 20 years/35 years & $1: 1.4$ \\
No HRT/HRT & $1: 1.3$ \\
No alcohol/alcohol $>$ 20 g daily & $1: 1.3$ \\
Low/high SES & $1: 1.1-2$ \\
\hline
\end{tabular}

Source: Kuhl H: Epidemiologie, Mammakarzinom und Hormonersatztherapie [17] (adapted).

tated breast cancer $1 / 2$ genes (BRCA1 and BRCA2) have a lifetime risk of developing breast cancer of $80-85 \%$ and of developing ovarian cancer of $15-65 \%$ [18].

- Place of birth: One consequence of birthplace is genetic difference; due to gene-environment interactions, women all over the world will have unequal breast cancer risks [19]. Environmental exposure at the birthplace is also a risk factor for developing breast cancer [20]. For example, women born in Turkey, Bosnia, Iraq, Iran, Africa, Asia and Chile have a $20-70 \%$ lower risk to develop breast cancer compared to women born in Western or Northern Europe or the USA [21].

- Reproductive factors: Several studies reveal a close correlation between reproductive factors and the risk of developing breast cancer.

\section{Increasing Risk}

The following factors increase the risk of developing breast cancer:

- Late menopause (>52 years)

- Early menarche ( $<12$ years)

- Nullipara

- Increased age at first birth

- Hormone replacement therapy (HRT): Recent data confirm a significant increase of risk during the intake of estrogen/progesterone preparations; the extent of increase depends on the duration of intake. After cessation of intake, the risk disappears fast. Only estrogen preparations show a considerably lower risk [17, 22, 23].

- Oral contraception: Current data do not show a clear risk increase [24]; however, more research has to be awaited.

- Breastfeeding: The available data do not allow a consensus on a protection through breastfeeding. There are details that the duration of breastfeeding is essential, not the number of breastfed children [25].

- Diet: Although the correlation between various aspects of diet (such as fat intake, fruit and vegetable consumption, vitamins, carbohydrate intake or consumption of soy products or green tea, etc.) and breast cancer risk has 

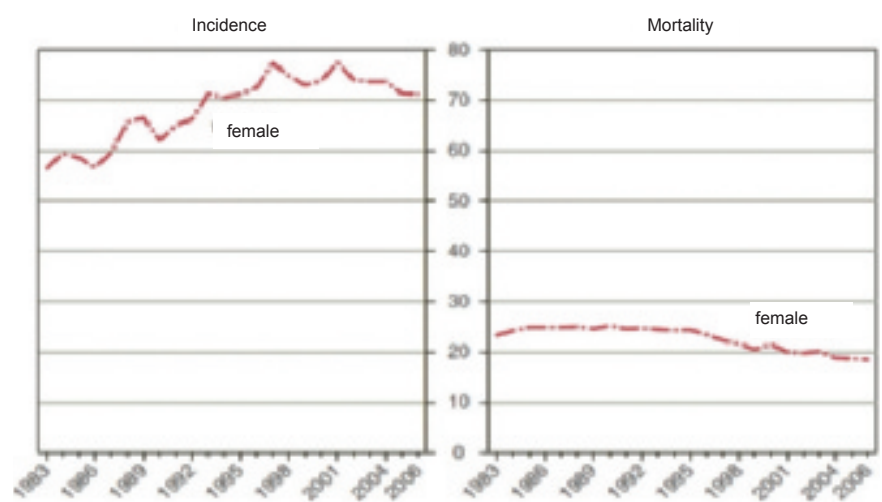

Fig. 1. Incidence and mortality of breast cancer in Austria, 1983-2006. Age-standardized rates/100,000 (World Health Organization (WHO) world population 2001). Source: Austrian Statistics Department, Austrian cancer registry.

been investigated in many studies in the last years, recent data only reveal a consistent and strong positive association with alcohol intake, being overweight, and weight gain [26]. Reasons for the lack of associations may be lack of causal association, measurement errors, foods containing carcinogenic compounds, differences in tumor characteristics or diet-gene interactions [27].

- SES: Several studies reveal a higher incidence of breast cancer in women of higher SES compared to women of lower SES [12-15].

Later age of first childbearing and low total parity are commonly associated with higher levels of education and higher SES, due to postponement of childbearing until after the completion of education and the consequent increase of maternal age. There has been a uniform shift towards later first childbearing in most European countries [28-30].

High SES is also associated with greater use of mammography screening and therefore with early detection of breast cancer, which may increase the incidence rates among women with high SES [31-33].

Another matter could be the disparity in HRT use between socioeconomic groups. The use of HRT was demonstrated to be significantly greater by women of higher SES [34, 35]. Between 1999 and 2005, a change in hormone use was observed, and it is estimated that this change reduced the risk for breast cancer by approximately $14 \%$ [36].

\section{Breast Cancer and Socioeconomic Variables in Austria}

With $28 \%$ of all cancers, breast cancer is the most common cancer in the female population, and incidence has shown a development similar to that in most of the Western European countries (fig. 1). Since 1997, however, the incidence is stabilizing. As seen in several countries, a drop in the breast cancer mortality rate is observable in Austria [6]. With an annual breast cancer mortality rate of 24.6/100,000 (1500 cases) Aus-
Table 2. Usage of mammography by education and employment status in Austria

\begin{tabular}{ll}
\hline Parameter & Mammography, \% \\
\hline Highest completed education & \\
$\quad$ Compulsory school & 57.0 \\
Apprenticeship/vocational middle school & 77.1 \\
High school/college & 76.8 \\
Cumulative & 69.4 \\
Acquisition status & \\
$\quad$ Employed & 80.2 \\
$\quad$ Unemployed & 75.7 \\
\hline
\end{tabular}

Source: Austrian Statistics Department, 2008.

tria is among the European average [1, 37]. In a comparison of 11 European countries, Austria was among the countries with the lowest rates of breast cancer mortality [14].

Treatment improvements, which are accessible to all patients countrywide due to the compulsory state insurance system, had a major impact on positive trends in mortality and survival. Opportunistic screening should have contributed to some extent, beginning in the early 1990s [38]; approximately 600,000 mammographies are done every year [39].

The health behavior of the Austrian population is determined by social factors [40]. There is a clear correlation between social classes and the prevalence of behavior-related risk factors such as, e.g., overweight: Women with compulsory education do have a 2.8 times higher risk for obesity than higher-educated women. The socioeconomic differences in Austria did not change markedly during the last decades. Life expectancy has a clear association with SES, as there are significant differences between university graduates and low-educated people: 6.2 years for men and 2.6 years for women [40, 41]. The use of early detection examination programs is much higher by high-educated people (table 2), who also assess their own health situation better than low-educated people. Social class-dependent risk behavior is an important reason for differences in mortality. People with a higher SES not only live longer than people with a lower SES, they also have a healthier lifestyle. Regardless of whether SES is defined by education, occupation, income or place of living, these differences can be observed in many studies in different countries [41, 42].

\section{Reproductive Factors}

Austrian girls experience their menarche on average with 12.2 years [43], one third with 12 years, $20 \%$ with 11 years, and $16 \%$ with 14 years or later [44].

The average age at the first pregnancy and birth is 29.8 years; the fertility rate is 1.38 [45]. The higher the educational level, the lower is the number of children. Comparing women at the age of 40 with compulsory education and female university graduates, they have 2.43 and 1.6 children, respectively. $23 \%$ of the female university graduates have no children, com- 
pared to $12 \%$ of the women with compulsory education [46] An older Austrian survey regarding breastfeeding showed that $46 \%$ of the women breastfed their child for 6 months. The higher the educational level and the higher the job performance, the longer was the breastfeeding period [47].

Regarding use of oral contraception, there are only few data available. Oral contraception is the most common contraception method, used by about one third of the women between 20 and 54 years [39]. The use of oral contraception depends on age: $54 \%$ of the younger women (15-19 years), but only $20 \%$ of the older women (40-45 years) use it.

Unfortunately, there are no available data concerning the use of HRT.

\section{Alcohol}

The Austrian per capita consumption of alcohol has increased since 1945, reached a maximum in the 1970s. Since then there is a slight decrease, of course still on a relatively high level. Up to $9 \%$ of the Austrian women are alcohol abusers; their daily consumption lies at about $40 \mathrm{mg}$ alcohol. Of the 330,000 alcohol abusers, one quarter are women $(82,000)$; abuse of alcohol and alcohol dependence are increasing among the female population. The relation of drinking men to drinking women has shifted from $4: 1$ to $3: 1$ during the last decade [48].

\section{Overweight and Obesity}

$29 \%$ of the Austrian girls and women are overweight, 13\% are obese $(460,000) .52 \%$ of the women with compulsory education are overweight, compared to $28 \%$ of the female university graduates. $20 \%$ of women with compulsory education go in for sports once a week, compared to $30 \%$ of the female university graduates [49].

\section{Self-Reported Morbidity}

Of the women with compulsory education $8 \%$ report a bad state of health (20\% are chronically ill), compared to only $1 \%$ of the female university graduates $(10 \%$ chronically ill). Only
$28 \%$ of the women with compulsory education do not have any health problems, compared to $41 \%$ of the female university graduates [49].

\section{Conclusion}

The higher breast cancer incidence in women with higher SES is an interesting phenomenon, which can be observed in many countries worldwide. The most important factors might be the later age of first childbearing and low total parity, which are commonly associated with higher levels of education and higher SES. Data confirm this trend also for Austrian women, who get their children later and who have a fertility rate of only 1.38 . Furthermore, women with higher education are more often childless than women with lower education. Greater use of HRT by women of higher SES may also be another parameter to explain the disparities between the socioeconomic groups. As there are no available data regarding the use of HRT, it is impossible to obtain an impression of the Austrian situation.

Of course, there is a clear correlation between different social classes and the prevalence of behavior-related risk factors in Austria. The differences between social classes can also be seen in the life expectancy of university graduates and loweducated people, with a difference of 6.2 years for men and 2.6 years for women.

Although major forward steps have been made with regard to screening and therapy, resulting in increased overall survival rates $[5,6]$, there is still the need for further investigation of the biologic, genetic and socio-cultural factors that may influence incidence, mortality and survival of breast cancer among different socioeconomic groups.

\section{Conflict of Interest}

The authors declare that there are no conflicts of interest.

\section{References}

1 Ferlay J, Bray F, Pisani P, Parkin DM: Globocan 2003. Cancer incidence, mortality and prevalence worldwide. IARC Cancer Base No. 5, Version 2.0. Lyon, IARC Press, 2004.

12 Porter P: 'Westernizing' women's risks? Breast cancer in lower-income countries. New Engl J Med 2008;358:213-216.

3 Curado MP, Edwards B, Shin HR, Storm H, Ferlay J, Heanue M, Boyle P (eds): Cancer incidence in five continents. Scientific Publications, No. 160. Lyon, IARC Press, 2007.

4 Ferlay J, Autier P, Boniol M, Heanue M, Colombet M, Boyle P: Estimates of the cancer incidence and mortality in Europe in 2006. Ann Oncol 2007; 18:581-592.
5 Sant M, Allemani C, Santaquilani M, Knijn A, Marchesi F, Capocaccia R: The Eurocare Working Group: Eurocare 4. Survival of cancer patients diagnosed in 1995-1999. Results and commentary. Eur J Cancer 2009;45:931-991.

6 Levi F, Bosetti C, Lucchini F, Negri E, La Vecchia $\mathrm{C}$ : Monitoring the decrease in breast cancer in $\mathrm{Eu}-$ rope. Eur J Cancer Prev 2005;14:497-502.

7 Woods LM, Rachet B, Coleman MP: Origins of socio-economic inequities in cancer survival: a review. Ann Oncol 2006;17:5-19.

8 Huisman M, Kunst AE, Bopp M, Borgan JK, Borrell C, Costa G, Deboosere P, Gadeyne S, Glickman M, Marinacci C, Minder C, Regidor E, Valkonen T, Mackenbach JP: Educational inequalities in cause-specific mortality in middle-aged and older men and women in eight Western European populations. Lancet 2005;365:493-500.
Avenando M, Kunst AE, Huisman M, Lenthe FV, Bopp M, Regidor E, Glickman M, Costa G, Spadea T, Deboosere P, Borrell C, Valkonen T, Gisser R, Borgan JK, Gadeyne JK, Mackenbach JP: Socioeconomic status and ischemic heart disease mortality in 10 Western European populations during the 1990's. Heart 2006;92:461-467.

10 Mackenbach JP, Huisman M, Andersen O, Bopp M, Borgan JK, Borrell C, Costa G, Deboosere P, Donkin A, Gadeyne S, Minder C, Regidor E, Spadea T, Valkonen T, Kunst AE: Inequalities in lung cancer mortality by the educational level in 10 European populations. Eur J Cancer 2004;40:126135.

11 Mackenbach JP, Stirbu I, Roskam AJ, Schaap MM, Manviella G, Leinsalu M, Kunst AE: Socio-economic inequalities in health in 22 European countries. N Engl J Med 2008;208:2468-2481. 
12 Dano H, Andersen O, Ewertz M, Petersen JH, Lynge E: Socio-economic status and breast cancer risk in Denmark. Int J Epidemiol 2003;32:218-224.

13 Strand BH, Tverdal A, Claussen B, Zahl PH: Is birth history the key to highly educated women's higher breast cancer mortality? A follow up study of 500,000 women aged 35-54. Int J Cancer 2005; 117:1002-1006.

14 Strand BH, Kunst A, Hujsman M, Menvielle G, Glickman M, Bopp M, Borell C, Borgan JK, Costa G, Deboosere P, Regidor E, Valkonen T, Mackenbach JP: EU: EU Working Group on Socio-economic Inequalities in Health: The reversed social gradient: Higher breast cancer mortality in the higher educated compared to lower educated. A comparison of 11 European populations during the 1990s. Eur J Cancer 2007;43:1200-1207.

15 Anderson WF, Rosenberg PS, Menashe I, Mitani A, Pfeiffer RM: Age-related crossover in breast cancer incidence rates between black and white ethnic groups. J Natl Cancer Inst 2008;100:1804-1814.

16 Dunitrescu RG, Cotarla I: Understanding breast cancer risk - where do we stand in 2005? J Cell Mol Med 2005;1:208-221.

17 Kuhl H: Epidemiologie, Mammakarzinom und Hormonersatztherapie. J Menopause 2003;10:5-9.

18 Emery J, Lucassen A, Murphy M: Common hereditary cancers and implications for primary care. Lancet 2001:358:56-63.

19 Harlap S, Olson S, Akhmadkhanov A, Barakat RR, Caputo T, Sanchez D, Xue X: Epithelial ovarian carcinoma and European birthplace of grandparents. Gynecol Oncol 2001;81:25-32.

20 Han D, Freudenheim JL, Nie J, Bonner M, Muti P, Trevisan M, Vito D, Edge S, Luyegu K, Shields P: Geographic differences in breast cancer cases and controls by genetic and biological characteristics: explaining clustering of breast cancer at place of birth. Proc Am Assoc Cancer Res 2005;46.

21 Sundquist J: The relevance of birthplace: The health of various immigrant groups in Sweden. Stockholm, National Institute of Public Health, 2004.

22 Cuzick J: Hormone replacement therapy and the risk of breast cancer. Eur J Cancer 2008;44:23442349.

23 Luzuy F: Hormonersatztherapie und Brustkrebsrisiko: aktuelle Situation. J Menopause 2005;12:22-24

24 Braendle W, Kuhl H, Mueck A, Birkhäuser M, Thaler C, Kiesel L, Neulen J: Erhöht die hormonale Kontrazeption das Tumorrisiko? Ther Umsch 2009;2:129-135.
25 Yang L, Jacobsen KH: A systematic review of the association between breastfeeding and breast cancer. J Womens Health 2008;10:1635-1645.

26 Lof M, Weiderpass E: Impact of diet on breast cancer risk. Curr Opin Obstet Gynecol 2009;21:80-85.

27 Michels KB, Mohallajee AP, Roset-Bahmanyar E, Beehler GP, Moysich KB: Diet and breast cancer: a review of the prospective observational studies. Cancer 2007;109:2712-2749.

28 Granström C, Sundquist J, Hemminki K: Population attributable risks for breast cancer in Swedish women by morphological type. Breast Cancer Res Treat 2008;111:559-568.

29 Brown SB, Cooke TG: Breast cancer incidence trends in deprived and affluent Scottish women. Breast Cancer Res Treat 2007;103:233-238.

30 Stefanov RS, Dimitrov ID: Between-birth intervals in newly married Bulgarian families. Folia Med (Plovdiv) 2005;47:70-77.

31 Blanchard K, Colbert JA, Puri D, Weissman J, Moy B, Kopans DB, Kaine EM, Moore RH, Halpern EF, Hughes KS, Tanabe KK, Smitz BL, Michaelson JS: Mammographic screening: patterns of use and estimated impact on breast carcinoma survival. Cancer 2004;101:495-507.

32 Lagerlund M, Maxwell AE, Bastani R, Thurfjell E, Ekbom A, Lambe M: Sociodemographic predictors of non-attendance at invitational mammography screening - a population based register study (Sweden). Cancer Causes Control 2002;13:73-82.

33 Puddu M, Demarest S, Tafforeau J: Does a national screening programme reduce socio-economic inequalities in mammography use? Int J Public Health 2009;54:61-68.

34 Friedman-Koss D, Crespo CJ, Bellantoni MF, Andersen RE: The relationship of race/ethnicity and social class to hormone replacement therapy: results from the 3rd National Health and Nutrition Examination Survey 1988-1994. Menopause 2002; 9:264-272.

35 Wei F, Miglioretti DL, Connelly MT, Andrade SE, Newton KM, Hartsfield CL, Chan KA, Buist DS: Changes in women's use of hormones after the Women's Health Initiative oestrogen and progestin trail by race, education and income. J Natl Cancer Inst Monogr 2005;35:106-112.

36 Parkin DM: Is the recent fall in incidence of postmenopausal breast cancer in UK related to changes in use of hormone replacement therapy? Eur J Cancer 2009;45:1649-1653.
7 Becker N: Entwicklung der Inzidenz und Mortalität an Brustkrebs. Radiologie 2001;41:337-343.

38 Vutuc C, Waldhoer T, Haidinger G: Cancer mortality in Austria: 1970-2002. Wien Klin Wochenschr 2004;116:669-675.

39 Österreichischer Frauengesundheitsbericht 2005/06. Vienna, Bundesministerium für Gesundheit und Frauen, 2006.

40 Klimont J, Ihie P, Baldaszti E, Kytir J: Sozio-demographische und sozio-ökonomische Determinanten von Gesundheit. Auswertung der Daten aus der österreichischen Gesundheitsbefragung 2006/07. Statistik Austria, 2008

41 Schwarz F: Socio-economic inequalities in health behaviour in Austria. Wien, Austrian Institute for Family Studies 2003, working paper 32 .

42 Mielck A: Soziale Ungleichheit und Gesundheit, in Hurrelmann K, Kolip P (Hrsg): Geschlecht, Gesundheit und Krankheit. Bern, Verlag Ernst Huber, 2002.

43 Kindergesundheitsbericht Wien 2000. Wien, MA-L I Dezernat für Gesundheitsplanung, 2000.

44 Weidinger B, Kostenwein W, Drunecky G: Das erste Mal. Sexualität und Kontrazeption aus Sicht der Jugendichen. Untersuchung im Auftrag der Österreichischen Gesellschaft für Familienplanung, 2001

45 Statistical Department Austria: Demographic trends in births, 2008

46 Hager M: Kinderlos glücklich? Gewollt kinderlose Akademikerinnen - Eine qualitative empirische Studie zur Lebenssituation und Zukunftsplanung österreichischer Akademikerinnen. Wien, LIT Verlag, 2006.

47 Österreichisches Bundesinstitut für Gesundheitswesen: Stillen in Österreich. Wien, Österreichisches Bundesinstitut für Gesundheitswesen, 1998.

48 Uhl A, Bachmayer S, Kobrna U, Puhm A, Springer A, Kopf N, Beiglböck W, Eisenbach-Stangl I, Preinsperger W, Musalek M (eds): Handbuch Alkohol - Österreich. Zahlen. Daten. Fakten. Trends. ed 3. Wien, Bundesministerium für Gesundheit, 2009.

49 Fonds Gesundes Österreich: 9. Präventionstagung - Soziale Ungleichheit und Gesundheit. Conference transcript, 2007. 